\title{
Oligochaeta (Annelida, Clitellata) of lotic environments at Parque Estadual Intervales (São Paulo, Brazil)
}

\author{
Roberto da Gama Alves ${ }^{1,4}$; Mercedes Rosa Marchese ${ }^{2}$; Renato Tavares Martins ${ }^{3}$ \\ ${ }^{I}$ Departamento de Zoologia, Instituto de Ciências Biológicas, Universidade Federal de Juiz de Fora - UFJF, \\ Campos Universitário Martelos, CEP 36036-900, Juiz de Fora, MG, Brazil \\ ${ }_{2}^{2}$ Instituto Nacional de Limnologia - INALI-CONICET-UNL, \\ José Maciá 1933 (3016) Santo Tomé, Santa Fe, Argentina, e-mail: mmarchese@datamarkets.com.ar \\ ${ }^{3}$ Programa de Pós Graduação em Ciências Biológicas, Comportamento e Biologia Animal, \\ Departamento de Zoologia, Instituto de Ciências Biológicas, Universidade Federal de Juiz de Fora - UFJF, \\ Campos Universitário Martelos, CEP 36036-900, Juiz, de Fora, MG, Brazil, martinsrt@ gmail.com \\ ${ }^{4}$ Autor para correspondência:Robertoda Gama Alves,e-mail: gama.alves@ufjf.edu.br
}

Alves, R. G.; Marchese, M. R.; Martins, R. T. Oligochaeta (Annelida, Clitellata) of lotic environments at Parque Estadual Intervales (São Paulo, Brazil). Biota Neotrop., vol. 8, no. 1, Jan./Mar. 2008. Available from: <http://www.biotaneotropica.org.br/v8n1/en/abstract?article+bn01708012008>.

\begin{abstract}
Studies on benthic macroinvertebrates of lotic environments usually focus on the occurrence, distribution, and richness of aquatic insects and decapod crustaceans. Only rarely these studies include the Oligochaeta. The aim of the present study was to examine the occurrence and species richness of Oligochaeta in different substrata patches of lotic environments. The studied included seven stream sites at Parque Estadual Intervales (São Paulo, Brazil). Stream sites differed in size and ranged from first to fourth order. In each stream, qualitative collections were made using a D-type net sampler with $0.21 \mathrm{~mm}$ mesh. Measures of $\mathrm{pH}$, electrical conductivity, dissolved oxygen, temperature and water turbidity were taken in the studied sites during collections of Oligochaeta. Specimens of the Tubificidae (including Naidinae) and Enchytraeidae families were collected. The Tubificidae Aulodrilus limnobius, Limnodrilus neotropicus and Limnodrilus hoffmeisteri were associated with low-flow habitats containing fine organic material. The most representative species among the Naidinae, Nais communis, was predominantly associated with rocky substrates present in fast current locations. The two other Naidinae species, Pristina osborni and Amphichaeta leydigi, presented low frequency in the studied streams. The Enchytraeidae family was present in only one of the sampled habitats.
\end{abstract}

Keywords: Atlantic Forest, Enchytraeidae, Tubificidae, Naidinae.

Alves, R. G.; Marchese, M. R.; Martins, R. T. Oligochaeta (Annelida, Clitellata) de ambientes lóticos do Parque Estadual Intervales (São Paulo, Brasil). Biota Neotrop., vol. 8, no. 1, jan./mar. 2008. Disponível em: <http://www.biotaneotropica.org.br/v8n1/pt/abstract?article+bn01708012008>.

Resumo: Estudos sobre macroinvertebrados bentônicos de ambientes lóticos geralmente focam na ocorrência, distribuição e riqueza de insetos aquáticos e de crustáceos decápodos. Tais estudos apenas raramente incluem Oligochaeta. O objetivo do presente estudo foi examinar a ocorrência e riqueza de espécies de Oligochaeta de diferentes substratos em ambientes lóticos. O estudo incluiu sete riachos do Parque Estadual Intervales (São Paulo, Brasil). Os riachos estudados variaram em tamanho desde primeira até quarta ordem. Em cada ambiente, foram realizadas coletas qualitativas utilizando amostrador do tipo rede em $\mathrm{D}$ com malha $0,21 \mathrm{~mm}$. Simultaneamente às coletas de Oligochaeta foram tomadas medidas do $\mathrm{pH}$, condutividade elétrica, oxigênio dissolvido, temperatura e turbidez da água dos ambientes. Foram coletados exemplares das famílias Tubificidae (incluindo Naidinae) e Enchytraeidae. Os Tubificidae Aulodrilus limnobius, Limnodrilus neotropicus e Limnodrilus hoffmeisteri estiveram associados à habitats com pouca correnteza e substrato contendo material orgânico fino. Nais communis espécie mais representativa entre os Naidinae, esteve predominantemente associada a substratos rochosos presentes em locais de correntes rápidas. As duas outras espécies de Naidinae, Pristina osborni e Amphichaeta leydigi apresentaram baixa freqüência nos córregos analisados. A família Enchytraeidae esteve presente somente em um dos ambientes amostrados.

Palavras-chave: Mata Atlântica, Enchytraeidae, Tubificidae, Naidinae. 


\section{Introduction}

There is a substantial literature on diversity of macroinvertebrates of small streams, although usually limited to insects, mainly Ephemeroptera, Plecoptera and Trichoptera. On the other hand, there is little information on Oligochaeta because they usually are not sampled or identified. However, many species of Oligochaeta occur in a variety of stream habitats. The oligochaetes have an important role in the processes of nutrient cycling (Losteste \& Marchese 1994) and energy flow (Aston 1984), making them important in aquatic food webs (Reynoldson \& Rodriguez 1999, Prygiel et al. 2000).

Studies on benthic macroinvertebrates of lotic environments from Parque Estadual Intervales (São Paulo, Brazil), which is a well preserved reserve (Melo \& Froehlich 2001a) with slopes and valleys covered by Atlantic Forest (Campos 2001), have focused on the occurrence, distribution, and richness of aquatic insects (Melo \& Froehlich 2001b, Salles et al. 2003, Crisci-Bispo et al. 2004, Pepinelli et al. 2005, Roque et al. 2005) and decapod crustaceans (Rocha \& Bueno 2004). However, no investigation has been conducted on the Oligochaeta.

The scarce knowledge of Oligochaeta in small order streams as well as the lack of information on this taxa in freshwater environments of the Atlantic Forest motivated the development of the present study. Specifically, we examined the occurrence and species richness of Oligochaeta in different substrata patches of lotic environments at the Parque Estadual Intervales.

\section{Material and Methods}

Substrate samples (fine sediments and rocks of different sizes) were obtained in seven streams (Três Córregos, Bocaina, Lageado, Água Comprida, Carmo, Roda D'Água and Rio das Mortes streams) at Parque Estadual Intervales (lat 24 $18^{\prime} \mathrm{S}$ and long $48^{\circ} 25^{\prime} \mathrm{W}$ ) in 2000 (December), 2001 (April, August and October) and 2002 (October). In each stream site, qualitative collections were made using a D-type net sampler (mesh size of $0.21 \mathrm{~mm}$ ) in different patches. The number of samples was not similar among streams. However, at least three samples were obtained in each stream during the study. The alive organisms were hand picked from samples in the field and preserved in 5\% formaldehyde. After 48 hours the specimens were transferred to $70 \%$ alcohol for subsequent counting and identification following the taxonomic criteria adopted by Brinkhurst \& Jamieson (1971), Righi (1984) and Brinkhurst \& Marchese (1989). The non-standardized sampling effort of collections did not allow a quantitative comparative analysis of the fauna between the streams, and thus the results are expressed in terms of relative abundance. Except in December 2000, the $\mathrm{pH}$, electrical conductivity, dissolved oxygen, temperature and water turbidity measurements were taken in each sampled stream.

\section{Results and Discussion}

The lotic environments studied were shallow (depth of 0.3 to $1.0 \mathrm{~m}$ ), with cold and transparent water, high oxygen concentration and $\mathrm{pH}$ varying from neutral to basic. Electrical conductivity was high except in the Três Córregos and Rio das Mortes sites (Table 1). The high conductivity of Bocaina, Lageado, Água Comprida, Carmo and Roda D'Água streams is associated with the local geology (calcareous rocks).

The benthic substrates were composed of rocks differing in size and, in areas near the banks with a reduced water flow, accumulated fine organic matter and leaves and branches from the terrestrial environment. These substrates are similar to those of the streams and mountain rivers studied by Dumnicka (1994a) in Poland, in which there is a predominance of Trichoptera, Plecoptera, Ephemeroptera, and Chironomidae, with Oligochaeta normally occurring infrequently. In the present study, the streams analyzed also were poorly represented by the Oligochaeta species, with 259 individuals obtained in total. Seven species belonged to the Tubificidae and Naidinae (Naididae was proposed as a subfamily within Tubificidae by Erséus \& Kallersjo 2004) were identified, with the highest species richness found in Três Córregos (four species). The five unidentified specimens of Enchytraeidae encountered belonged to a single morphotype (Table 2).

The current speed, organic matter structure (diameter of fragments) and mineral substrates (grain size) are important factors in distribution and abundance of Oligochaeta (Martinez-Ansemil \& Collado 1996, Sauter \& Gude 1996, Verdonschot 1999). In our study, the Tubificidae Aulodrilus limnobius, Limnodrilus neotropicus, and L. hoffmeisteri were associated with slow flow habitat containing fine organic matter and leaves and branches from the terrestrial environment. Our results agree with previous studies indicating that this family is generally associated with soft substrates (Dumnicka \& Kukula 1990) and usually do not occur in environments with rocky bottoms and fast currents (Kasprzak \& Szczesny 1976, Dumnicka \& Kukula 1990, Schenková \& Helesic 2006).

Limnodrilus hoffmeisteri can be found in a wide variety of conditions (Brinkhurst \& Marchese 1989), and can inhabit either organically polluted environments (Marchese \& Ezcurra de Drago 1999, Prygiel et al. 2000, Alves \& de Lucca 2000, Alves et al. 2006) and environments with no human interference, as observed in this study. Aulodrilus limnobius lives in the superficial layer of the sediments and feeds on organic matter, agglutinating particles to build tubes (Marcus 1944). In fact, this species presented a higher relative abundance in patches composed of sandy sediment.

Of the three Tubificidae species L. neotropicus was the most infrequent. In a previous study in São Paulo (Água Branca and Gouveia streams), this species was collected in the sandy patches containing considerable amounts of branches and leaves (Alves et al. 2006).

Table 1. Environmental variables (average value) measured in seven stream sites in the Parque Estadual Intervales in 2001 and 2002.

Tabela 1. Variáveis ambientais (valores médios) medidos em sete córregos localizados no Parque Estadual Intervales em 2001 e 2002.

\begin{tabular}{|c|c|c|c|c|c|c|c|}
\hline & Coordinates & Order & pH & $\begin{array}{c}\text { Electrical } \\
\text { conductivity } \\
\left(\mu \mathrm{S} . \mathrm{cm}^{-1}\right)\end{array}$ & $\begin{array}{c}\text { Temperature } \\
\left({ }^{\circ} \mathrm{C}\right)\end{array}$ & $\begin{array}{c}\text { Dissolved } \\
\text { oxygen } \\
\left(\mathrm{mg.L} \mathbf{L}^{-1}\right) \\
\end{array}$ & $\begin{array}{c}\text { Turbidity } \\
\text { (NTU) }\end{array}$ \\
\hline Três Córregos & $24^{\circ} 19^{\prime} \mathrm{S}$ and $48^{\circ} 23^{\prime} \mathrm{W}$ & third & 7.04 & 21.20 & 17.7 & 9.60 & 1.7 \\
\hline Córrego Bocaina & $24^{\circ} 16^{\prime} \mathrm{S}$ and $48^{\circ} 27^{\prime} \mathrm{W}$ & second & 8.28 & 121.40 & 17.5 & 9.27 & 1.6 \\
\hline Carmo & $24^{\circ} 18^{\prime} \mathrm{S}$ and $48^{\circ} 25^{\prime} \mathrm{W}$ & fourth & 8.07 & 172.60 & 16.1 & 9.76 & 1.3 \\
\hline Ribeirão Lageado & $24^{\circ} 18^{\prime} \mathrm{S}$ and $48^{\circ} 24^{\prime} \mathrm{W}$ & fourth & 8.97 & 180.20 & 17.2 & 8.84 & 1.7 \\
\hline Roda D’água & $24^{\circ} 16^{\prime} \mathrm{S}$ and $48^{\circ} 25^{\prime} \mathrm{W}$ & first & 7.10 & 162.35 & 17.0 & 7.42 & 2.0 \\
\hline Ribeirão Água Comprida & $24^{\circ} 17^{\prime} \mathrm{S}$ and $48^{\circ} 25^{\prime} \mathrm{W}$ & third & 7.16 & 178.20 & 18.8 & 8.45 & 2.9 \\
\hline Rio das Mortes & $24^{\circ} 20^{\prime} \mathrm{S}$ and $48^{\circ} 26^{\prime} \mathrm{W}$ & fourth & 7.16 & 31.20 & 16.9 & 7.95 & 3.6 \\
\hline
\end{tabular}


Oligochaeta at Parque Estadual Intervales

Table 2. Relative abundance (\%) and number of specimens (in round brackets) of Oligochaeta species of the seven sampled streams in the Parque Estadual Intervales.

Tabela 2. Abundância relativa (\%) e número de espécimes (entre parênteses) de espécies de Oligochaeta dos sete córregos amostrados no Parque Estadual Intervales.

\begin{tabular}{|c|c|c|c|c|c|c|c|}
\hline & 1 & 2 & 3 & 4 & 5 & 6 & 7 \\
\hline \multicolumn{8}{|l|}{ Tubificidae } \\
\hline Limnodrilus hoffmeisteri Claparede, 1862 & $30.77(8)$ & $0.93(1)$ & $7.14(2)$ & 0.00 & 0.00 & $15.22(7)$ & $11.76(2)$ \\
\hline Limnodrilus neotropicus Cernosvitov, 1939 & $57.69(15)$ & 0.00 & 0.00 & 0.00 & 0.00 & 0.00 & $47.06(8)$ \\
\hline Aulodrilus limnobius Bretscher, 1899 & $3.85(1)$ & $98.15(106)$ & $10.71(3)$ & 0.00 & 0.00 & $80.43(37)$ & $41.18(7)$ \\
\hline \multicolumn{8}{|l|}{ Naidinae } \\
\hline Nais communis Piguet, 1906 & 0.00 & $0.93(1)$ & $82.14(23)$ & $100.00(2)$ & $84.38(27)$ & 0.00 & 0.00 \\
\hline Amphichaeta leydigi Tauber, 1879 & $7.69(2)$ & 0.00 & 0.00 & 0.00 & 0.00 & 0.00 & 0.00 \\
\hline Pristinella osborni (Walton, 1906). & 0.00 & 0.00 & 0.00 & 0.00 & 0.00 & $4.35(2)$ & 0.00 \\
\hline \multicolumn{8}{|l|}{ Enchytraeidae } \\
\hline Unidentified species & 0.00 & 0.00 & 0.00 & 0.00 & $15.63(5)$ & 0.00 & 0.00 \\
\hline
\end{tabular}

Streams: 1 = Três Córregos; 2 = Bocaina; 3 = Lageado; 4 = Água Comprida; 5 = Carmo; 6 = Roda D'Água; and 7 = Rio das Mortes.

Córregos: 1 = Três Córregos; 2 = Bocaina; 3 = Lageado; 4 = Água Comprida; 5 = Carmo; 6 = Roda D’Água; 7 = Rio das Mortes.

Among the Naidinae, Nais communis was mainly associated with rocky substrates present in fast current areas. This agrees with Dumnicka (1994b) that found this species in mud-covered stones in first order streams in Poland. This habitat offers protection from predators (Dumnicka 1994a) and algae as food resource to this species (Kasprzak \& Szczesny 1976). The periphyton associated with rocky substrates is an important factor in Naidinae species distribution (Bingham \& Miller 1989). In Europe, N. communis is found in different water bodies and is common in mountainous streams (Dumnicka 1982). The two other Naidinae species, Pristina osborni and Amphichaeta leydigi were infrequent in the studied streams.

The Enchytraeidae family is common in streams with coarse granulometry, fast speed currents and high oxygen content (Lencioni $\&$ Maiolini 2002). In Europe, it is usually present at high altitude environments (Dumnicka 1994a, Dumnicka \& Kukula 1990). In the present study, this family presented low frequency of occurrence.

\section{Acknowledgments}

The authors would like to thank The Fundação de Amparo à Pesquisa do Estado de São Paulo (FAPESP) (process no. 98/05073-4.).

\section{References}

ALVES, R.G. \& DE LUCCA, J.V. 2000. Oligochaeta (Annelida: Clitellata) como indicador de poluição orgânica em dois córregos pertencentes à Bacia do Ribeirão do Ouro Araraquara (São Paulo-Brasil). Braz. J. Ecol. 4(1-2):112-117.

ALVES, R.G., MARCHESE, R.M. \& ESCARPINATI, S.C. 2006. Oligochaeta (Annelida, Clitellata) in lotic environments in the state of São Paulo, Brazil. Iheringia Sér. Zool. 96(4):431-435.

ASTON, R.J. 1984. The culture of Branchiura sowerbyi (Oligochaeta: Tubificidae) using cellulose substrate. Aquaculture 40(1):89-94.

BINGHAM, C.R. \& MILLER, A.C. 1989. Colonization of a man-made gravel bar by Oligochaeta. Hydrobiologia 180(1):229-234.

BRINKHURST, R.O. \& JAMIESON, B.G.M. 1971. Aquatic Oligochaeta of the World. University of Toronto. Toronto.

BRINKHURST, R.O. \& MARCHESE, M.R. 1989. Guia para la indentificación de oligoquetos acuáticos continentales de Sud y Centroamérica. Clímax. Santa Fé, Argentina.

CAMPOS, F.P. 2001. Parque Estadual Intervales e o serviço de áreas naturais protegidas. In Intervales: Fundação para a Conservação e a Produção
Florestal do Estado de São Paulo. São Paulo, Secretaria de Estado do Meio Ambiente de São Paulo, p.11-19.

CRISCI-BISPO, V.L., BISPO, P.C. \& FROEHLICH, C.G. 2004. Triplectides larva in empty cases of Nectopsyche (Trichoptera, Leptoceridae) at Parque Estadual Intervales, São Paulo, Brazil. Rev. Bras. Entomol. 48(1):133-134.

DUMNICKA, E. 1982. Stream ecosystems in mountain grassland (West Carpathiana). Acta Hydrobiol. 24(4):391-398.

DUMNICKA, E. 1994a. Communities of Oligochaeta in mountain streams of Poland. Hydrobiologia, 278(1-3):107-110.

DUMNICKA, E. 1994b. Habitat preferences of invertebrates (especially Oligochaeta) in a stream. Acta Hydrobiol. 36(1):91-101.

DUMNICKA, E. \& KUKULA, K. 1990. The communities of oligochaetes of the Wolosatka and Terebowiec streams (the Bieszczady) National Park, southeastern Poland. Acta Hydrobiol. 33(3/4):423-435.

ERSEUS, C. \& KALLERSJO, M. 2004. 18s rDNA phylogeny of Clitellata (Annelida). Zool. Scr. 33(2):187-196.

KASPRZAK, K. \& SZCZESNY, B. 1976. Oligochaetes (Oligochaeta) of the River Raba. Acta Hydrobiol. 18(1):75-87.

LENCIONI, V. \& MAIOLINI, B. 2002. L'ecologia di un ecosistema acquatico alpino (Val de la Mare, Parco Nazionale dello Stelvio). Natura Alpina 54(4): $1-96$.

LOTESTE, A. \& MARCHESE, M. 1994. Ammonium excretion by Paranadrilus descolei Gavrilov, 1955 and Limnodrilus hoffmeisteri Claparéde, 1862 (Oligochaeta: Tubificidae) and their role in nitrogen delivery from sediment. Pol. Arch. Hydrobiol. 41(2):189-194.

MARCHESE, M. \& EZCURRA de DRAGO, I.E. 1999. Use of benthic macroinvertebrates as organic pollution indicators in lotic environments of the Paraná River drainage basin. Pol. Arch. Hydrobiol. 46(3-4):233-255.

MARCUS, E. 1944. Sobre Oligochaeta límnicos do Brasil. Bol. Zool. 8:5-101.

MARTINEZ-ANSEMIL, E. \& COLLADO, R. 1996. Distribution patterns of aquatic Oligochaeta inhabiting watercoursers in the Northwestern Iberian Península. Hydrobiologia 334(1-3):73-83.

MELO, A.S. \& FROEHLICH, C.G. 2001a. Macroinvertebrates in neotropical streams: richness patterns along a catchment and assemblage structure between 2 seasons. J. N. Am. Benthol. Soc. 20(1):1-16.

MELO, A.S. \& FROEHLICH, C.G. 2001b. Evaluation of methods for estimating macroinvertebrate species richness using individual stones in tropical streams. Freshw. Biol. 46(6):711-721.

PEPINELLI, M., TRIVINHO-STRIXINO, S. \& HAMADA, N. 2005. Imaturos de Simuliidae (Diptera, Nematocera) e caracterização de seus 
criadouros no Parque Estadual Intervales, SP, Brasil. Rev. Bras. Entomol. 49(4):527-530.

PRYGIEL, J., ROSSO-DARMET, A., LAFONT, M., LESNIAK, C., DURBEC, A. \& OUDDANE, B. 2000. Use of oligochaete communities for assessment of ecotoxicological risk in fine sediment of rivers and canals of the Artois-Picardie water basin (France). Hydrobiologia 410(0):25-35.

REYNOLDSON, T.B. \& RODRIGUEZ, P. 1999. Field methods and interpretation for sediment bioassessment. In Manual of Bioassessment of Aquatic Sediment Quality. (A. Mudroch, J.M. Azcue \& P. Mudroch eds.). Lewis Publishers, Boca Ratón, Florida, USA, p.135-175.

RIGHI, G. 1984. Manual de identificação de invertebrados límnicos do Brasil. Coordenação Editorial, CNPq. Brasília.

ROCHA, S.S. \& BUENO, S.L.S. 2004. Crustáceos decápodes de água doce com ocorrência no Vale da Ribeira de Iguape e rios costeiros adjacentes, São Paulo, Brasil. Rev. Bras. Zool. 21(4):1001-1010.

ROQUE, F.O., SIQUEIRA, T. \& TRIVINHO-STRIXINO, S.T. 2005. Occurrence of chironomid larvae living inside fallen-fruits in Atlantic Forest streams, Brazil. Entomol. Vectores 12(2):275-282.
SALLES, F.F., FRANCISCHETII, C.N., ROQUE, F.O., PEPINELLI, M. \& TRIVINHO-STIXINO, S. 2003. Levantamento preliminar dos gêneros e espécies de Baetidae (Insecta: Ephemeroptera) do estado de São Paulo, com ênfase em coletas realizadas em córregos florestados de baixa ordem. Biota Neotrop. 3(2): http://www.biotaneotropica.org.br/v3n2/ pt/abstract?short- communication+BN01103022003 (último acesso em 01/06/2007)

SAUTER, G. \& GUDE, H. 1996. Influence of grain size in distribution of tubificid oligochaete species. Hydrobiologia 334(1-3):97-101.

SCHENKOVÁ, J. \& HELEŠIC, J. 2006. Habitat preferences of aquatic Oligochaeta (Annelida) in the Rokttná River, Czech Republic- a small highland stream. Hydrobiologia 564(1):117-126.

VERDONSCHOT, P.F.M. 1999. Micro-distribuition of oligochaetes in a softbottomed lowland stream (Elsbeek; The Netherlands). Hydrobiologia 406(5-7):149-163.

Recebido em 27/07/07 Versão reformulada recebida em 21/12/07 Publicado em 29/01/08 